\title{
Attitudes of Jerusalem students towards the Palestinian Resistance Literature (PRL)
}

Barakat, Heba I.A.a hiba_, Ortega Martin, J. Luisa. ,Hafez Zeidan, Afif.

Abstract

This paper aims to identify the attitudes of students towards the Palestinian Resistance Literature (PRL) and the role of some variables (gender, stage and place of residence) in determining students' attitudes towards PRL. The study population consisted all students in the schools of Jerusalem. The sample $(1,302)$ was withdrawn using the cluster random method. We constructed a questionnaire comprised 58 items to measure the attitudes of Palestinian students towards PRL. We used descriptive methods- mathematical averages, standard deviations, and percentages- and analytical methods - t-test and one-way ANOVA. The findings show that the level of attitudes of Jerusalem students towards PRL was high across all domains in terms of the role of PRL in general; attitudes towards Palestinian resistance poetry; attitudes towards an environment rich in Palestinian resistance literature. This shows the importance of PRL in the lives of the Palestinian people due to its major role in confronting occupation. In addition, the results indicated there are no statistically significant differences in the attitudes of students towards PRL attributable to the sex variable. Further, there are statistically significant to the stage variable in favor of the elementary stage and the residence variable in favor of refugee camps.

Keywords: student attitudes; Literature; Palestinian Resistance Literature; Jerusalem; Arab language; Curriculum

\section{Introduction:}

The psychological trend is considered as a preparation that is acquired as a result of the experiences that an individual has, and which ameliorates gradually to take fixed forms that affect the individual's attitude, his relationships with others and how he sees the different aspects of life. It starts as innocent scattered conflicts, which will quickly be harmonized, bound and held together in a clear way. Trends are the central and main subject of psychology; it generally includes the individual's specific understanding of political, economical,

\section{1}


religious or social issues about individuals or groups. The latter issues may be considered as the real embodiment of objects or actions (Dowidar, 1998). Trends indicate tendencies that enable the individual to respond and react in specific behavioral patterns towards people, ideas, events, conditions or certain things and make up a complex system where a large group of diverse variables interact together. Any attempt to analyze the nature of the trends or its dynamics would involve the simplification of this nature, because trends are behavioral patterns that can be acquired and modified through learning, and they are subjected to the rules and principles that control other behavioral patterns (Nashwani, 1985).

Literature is the brainchild of the creative self in term of feelings, visions and imagination; it is a luminosity of the mind bathed with emotions of warm sadness. Resistance literature tops all other genres across all times and places, simply because it is embedded deep in the being of the people and the land (Jomaa, 2009). It may be difficult to study the literature life of the Palestinian people without taking into consideration its special circumstances. The first aspect in this regard is the events that took place during and after the 1948 War that left part of Palestinians inside the occupied land suffering from suppression and occupation, while others fled to refugee camps in the Gaza Strip, Jordan, Lebanon and Syria and lived in very inhumane conditions. These people were forced to face the invasion of organized criminals supported by external powers. When we consider the literature evolution we will find two distinct phases; the first one is between 1948 and until the 1960s, and the other starts from the middle of the 1960s when Palestinian armed action formally started and was paralleled by an evolution of Palestinian thought and literature. The features of this evolution were further

\section{2}


embodied after the massive defeat in the June 1967 War (Kanafani, 1980). PRL has always been a reflection of reality picture and a mirror by which writers and thinkers reveal their private vision about that reality and society they live at Poetic and prose language of literature including the various literary forms such as novel, story, poem (Kanafani, 1970).

Attitudes are tendencies that qualify the individual to respond with certain behavioral modes to other individuals, ideas, positions or things, which interrelate in a complex system wherein a large group of variables interact with one another. They are learned and evaluative concepts that relate to our thoughts, feelings and behaviors (Davidoff, 1980). It is a relatively constant system of positive or negative evaluation of feelings towards a certain social issue (Al-Kubaisy \& AlDahery, 2000). In this study, attitudes are measured by the mark scored by the students on the scales developed specifically for this study.

Jerusalem City, The largest city in the Palestine, it is a holy city for both Islam and Christianity. In 1948, a part of Jerusalem was occupied by the Israelis (West Jerusalem) while Jordan took control of the other part (East Jerusalem) which includes the Old Town. Israel occupied East Jerusalem in the 1967 Six-Day War, combining the two parts under its authority thereafter.

There is a substantial volume of research about attitudes, for example, establishing students' interests in, or attitudes towards, science or scientists (e.g., Lehrke, Hoffmann \& Gardner, 1985; Hoffmann, Krapp, Renninger \& Baumert, 1998; Tamir \& Gardner, 1989; Simpson, Koballa, Oliver \& Crawley, 1994; Jenkins \& Nelson, 2005); the effects of teaching spoken Arabic on students' attitudes and motivation in Israel (Schmidt et al, 2004); Attitude of medical students

\section{3}


towards general practice (Henderson, 2002). As far as the researchers are aware, this study is the first of its kind to address the relationship between attitudes towards Palestinian resistance (revolutionary) literature among students in Palestine.

We constructed a scale for student's attitudes towards PRL based on previous scales, Palestinian curricula and references related to PRL after processing educational literature related to the study. We built the questionnaire comprised 58 items to measure the attitudes of Palestinian students towards PRL.

Our paper aims to identify the attitudes of students towards the PRL and the role of some variables (gender, stage and place of residence) in determining students' attitudes towards PRL.

This paper contributes to the literature; this study develops a comprehensive set of student's attitudes towards PRL based on previous scales, Palestinian curricula and references related to PRL. This study is the first of its kind in Palestine to address the relationship between attitudes towards Palestinian resistance (revolutionary) literature among students.

The remainder of this paper is structured as follows. Section one reviews the Palestinian resistance literature. Section two study questions and hypotheses. Section three, four, five significance of the study, limitations of the study and terminology. Section six explains the methodology used to satisfy the objectives of the study. Section seven reports the analysis and results of the study. The last section leads to discussion and recommendations.

\section{Palestinian Resistance Literature}

\section{Factors of Emergence of PRL}

In 1908 when Ottoman constitution was issued, the late Sheik Mohammad Saleh, upon a patriotic motive, established "Kindergarten of Fayhaa" which disappeared during the First

\section{4}


World War. After British occupation of Palestine, Sheik Mohammad Saleh with a group of his friends established a national school called "Kindergarten of National Knowledge" where it was a national institution to graduate the young people of Palestine, Jordan, and Iraq; this national institution kept performing its cultural, moral, and national role until the second disaster "Nakba" in the 1967. In 1909, Khalil Skakini established the School of Constitution to educate the young men; it was characterized by having students with various religions and ideas, reinforcing, educating, encouraging students, and planting spirit of courage and prowess into them (Al-Jozi, 1990). After the end of the First World War and collapse of Ottoman influence in the Arab countries, Palestine was put under the British Mandate within bad political circumstances, Balfour Declaration was issued in November 1917 by which Jews established their National Home in Palestine. In 1922, League of Nations approved the Mandate where Britain sought to create the political and economical conditions in order to Judaize Palestine and facilitate immigration to it. To defend their homeland, Palestinian people spared no efforts, held several conferences, and performed a lot of revolutions such as Al-Buraq Revolution when the British courts in Palestine delivered judgments of imprisonment and death by execution on the martyrs: Mohammad Jamjoum, Ata Azzir, and Fuad Hijazi.

The conflict continued until Palestine disaster (Nakba) that occurred in 1948; the Zionist gangs occupied Palestine and displaced Palestinian people, and in June 1967, the Zionist entity occupied the rest of Palestine (AL-Owaisi, 1992).

This paper exceeds limits of Palestine disaster with all dates of its bloody events and exceeds the age of this Zionist entity that resulted in the global colonization, where it takes up total of

\section{5}


political and social reasons, which destroyed the Palestinian entity and caused emergence of bastard of colonization. At the eve of world war, the international position was controlled by the Zionist leaders in all powerful countries; in Germany, the Zionists made an agreement with its leaders resulted in support of the German government to Jewish and Zionist activities and Jewish settlement in Palestine, while in Britain there was Balfour declaration in 2nd November 1917 "unholy marriage certificate between the British Imperialism and the colonial Zionist movement against Palestinian people", but in America, the leader of Zionist movement "Louis Brandeis" was a powerful man as to U.S president "Wilson" that this Zionist judge managed to push the United States to support Britain in its war if the latter agrees to establish a Jewish homeland in Palestine. This shows that, immediately after the World War, three major countries supported the Zionists against Palestinian people which resulted in occupation of a homeland and displacement of its entire people, where depraved Zionist objectives were supported by all western countries (Al-Kayali, 1973).

In this context, the Palestinian people got frightened since they felt from the beginning that their future would be dark. It was clear for observers of that period 1914-1919, that the calamity of the Palestinian people became a large tragedy, thus, their reactions were not confined to protest and words, rather secret and non-secret societies were formed where armed teams were established to assassinate some Jewish leaders. The whole western world supported the lame Zionism to be built upon the Palestinian entity (Al-Hussein, 1980). The Arabs of the occupied Palestine realized, from the beginning, seriousness of the battle they were facing under Israeli military rule, and from the beginning, they showed their awareness of the plan

\section{6}


fabricated against them and summarized it in one short sentence, namely, "all people in the world stand on their feet except the military governor who stands on his tails". This expression was not able to face the political and cultural challenge fabricated against them, where such awareness led to clarify the Resistance Literature which was a resistance from the inside to facilitate the attack from the outside (Kanafani, 1980).

The term PRL was commonly used after June 1967, and after the political, military, and cultural emergence of Palestinian resistance movement that appeared after the military and psychological defeat of Arab countries in June, the duty of Palestinian intellectuals toward their commitment to their issue was to move the inactive culture of the rural areas that they played a key role to develop a considerable awareness. There was a close relationship between Palestinian folk literature and the eloquent literature in the cities on one hand, and the Palestinian resistance movement on the other hand; such relation was not descriptive or documentary as it was a deep dialectical relationship, this maybe started in the 1930s, when such period was full of a great group of poets and tellers who roused the armed struggle and made it a part of the cultural heritage (Al-Hussein, 1980).

\section{Poetry and Prose in PRL (stories, novels, plays)}

The poetry is expected to be the first tool in calling for resistance; since it can spread without being published and it can transfer verbally. The poetry in the occupied territory has never stopped performing its role in resistance using all tools that can be employed in order to make it a weapon when needed; The popular poetry has played a significant role in history of Palestine since the 1920s; in fact, the Palestinian people are those who transferred the songs and ovations to

\section{7}


their exiles that are evidently noticed in all demonstrations in the Levant (Kanafani, 1970). There are various dimensions of heroism in the contemporary Arab resistance due to the different fronts in which the Arab person struggle; the Palestinian front, for example, is not mere a conflict between the Arab and the western colonization, it is further a hard conflict between state of Israel and Palestinian people, the core of Palestinian poetry is liberation of the land (Shukri, 1979).

The most famous poets of Palestinian resistance: Ibrahim Toukan, Mahmoud Darwish, Abd Al-Karim Al-Karmi, Samih Al-Qasim, Tawfiq Ziad, Abd Al-Rahim Mahmoud, Wadie' Al-Bustani, Ahmad Dahbour, Fadwa Toukan, Al-Mutawakel Taha and Ma'n Bsiso (Sadouq, 2000).

The modern and contemporary Arab literature has experienced certain political and cultural conditions resulted in various literary trends, specially the story. Our writers mainly depended on the European literature; accordingly, they considered the foreign story ideal in terms of their trip in the story writing, so they translated a lot of works, that the new circumstances of the Palestinian people had a great impact on selecting characters by the Palestinian writer (Abu Al-Shabab, 1977). The story of heroism and the story of resistance have not been equivalent unless the story of resistance is combined with the story of heroism, then we got a terrific story so long as the writer has the artistic talent and ability that sorts it out in the a mature level of human action (Shukri, 1979). Palestinian intellectual learnt about the world's great stories translated by the foreign missionaries at the beginning of the twentieth century (Rashid, 2004). Of the most prominent writers in prose Palestinian resistance; Samira Azzam, Ghassan Kanafani, Jabra Ibrahim Jabra and Tawfiq Fayyad.

\section{8}




\section{Study Questions and Hypotheses}

Question 1: What are the attitudes of students in Jerusalem towards Palestinian resistance (revolutionary) literature?

Question 2: What is the impact of some variables (sex, stage, and residence) on attitudes towards Palestinian literature among students in Jerusalem?

Hypothesis 1: There are no statistically significant differences at the level of significance $(\alpha \geq 0.05)$ between average attitudes towards Palestinian literature among students in Jerusalem that are attributed to the sex variable.

Hypothesis 2: There are no statistically significant differences at the level of significance $(\alpha \geq 0.05)$ between average attitudes towards Palestinian literature among students in Jerusalem that are attributed to the stage variable.

Hypothesis 3: There are no statistically significant differences at the level of significance $(\alpha \geq 0.05)$ between average attitudes towards Palestinian literature among students in Jerusalem that are attributed to the residence variable.

\section{Significance of the Study}

The significance of this study is characterized through the following:

1. As far as the researchers are aware, this study is the first of its kind in Palestine to address the relationship between attitudes towards Palestinian resistance (revolutionary) literature among students.

2. Curriculum designers across all school stages are expected to benefit from this study. PRL is not only a product of poets and writers; it is a culture of people.

3. Teachers are expected to benefit from this study in concentrating on some terms and concepts that are closely related to PRL and culture.

\section{9}


4. The Ministry of Education may benefit from this study by introducing a curriculum that enhances students' awareness of Palestinian resistance literature.

5. The Ministry of Education may benefit from this study by integrating some of its chapters into our Palestinian curricula.

\section{Limitations of the Study}

Human limitations: All elementary and secondary students in Jerusalem City.

Time limitations: 2012-2013

Procedural limitations: The study's procedures are limited to the selection method of the study population, sample and tools.

Conceptual limitations: The concepts of this study are limited to its terms and definitions.

\section{Study Terminology}

Resistance literature: The literature that addresses group and individual, known and unknown heroisms against invaders and tyrants. The social dimension in resistance literature is among the important aspects that add up to the human and nationalist dimensions. Resistance literature focuses on contemporary popular struggle; it emphasizes the prevalence of teaching in standard Arabic and prioritizes the use of this language in expression. Therefore standard Arabic has become the main foundation of resistance literature (Shukri, 1979).

Palestinian resistance literature: The literature that resists anything that might harm the individual or the group from within and stand against the Zionist occupation of Palestine. Literature and writers bear the responsibility of strengthening wills, raising awareness and documenting resistance in order to stimulate the Palestinian community to grasp to its moral, domestic and national traditions and values (Jomaa, 2009).

\section{0}


The act of resistance refers to standing up against tyranny and occupation. It further implies rejection, rebellion, disobedience and revolution. Resistance literature is an intellectual product that plays the role of rejection and rebellion in the time of occupation in order to drive and motivate crowds towards refusing all forms of imperialism and oppression, maintaining their existence and safeguarding the foundations of this existence such as religious, academic, traditional and social practices. It is also a method of confronting all forms of imperialism and oppression, whereby spoken or written words replace shields and gunpowder in battlefields. Whereas the effects of war arms expire once they are used, the impacts of words of resistance continue long after they are written or spoken, as much as their potential for affection and survival (Al-Hussein, 1980).

It is the literature works of the Occupied Land's Arabs. PRL concentrates on the conditions and factors of its origination. It is the brightest aspect of the struggle of the oppressed people. Through this literature, Arab readers in general and Palestinian refugees in particular, can browse the intellectual and literature struggle of the Palestinian people since Palestine fell under the Zionist occupation, its land has been occupied, and its people have been displaced (Kanafani, 1980).

Knowledge about Palestinian resistance literature: The student's awareness of the various aspects related to PRLin poetry and prose. It is measured in this study using the mark scored by the student on the scale developed specifically for this study.

Attitudes: are tendencies that qualify the individual to respond with certain behavioral modes to other individuals, ideas, positions or things, which interrelate in a complex system wherein a large group of variables interact with one another.

\section{1}


They are learned and evaluative concepts that relate to our thoughts, feelings and behaviors (Davidoff, 1980). It is a relatively constant system of positive or negative evaluation of feelings towards a certain social issue (Al-Kubaisy and AlDahery, 2000). In this study, attitudes are measured by the mark scored by the students on the scales developed specifically for this study.

Student: An individual pursuing education in the elementary, preparatory or secondary stage. $\mathrm{He} / \mathrm{she}$ receive knowledge with initial mental astonishment, which makes educational and learning processes accompanied by special psychological, mental and behavioral reactions. As a learner, the student receives literature and cultural messages directed thereto through textbooks, which should entice positive or negative reactions and responses.

\section{Methodology}

The researcher used the descriptive correlation method as a research methodology in this study, because it is suitable to its purposes.

\section{Population and sample}

The study population consisted all students $(n=68,493)$ in the schools of Jerusalem. The sample was withdrawn using the cluster random method after obtaining the official records endorsed by the Ministry of Education for students registered in academic year 2012/2013. The sample consisted of 1,302 students.

\section{Study tools}

We built questionnaire, it composed of five sections and the questionnaire contains 58 items to measure the attitudes of Palestinian students towards Palestinian resistance literature. Our questionnaire based on previous scales, Palestinian curricula and references related to PRL after processing

\section{2}


educational literature related to the study. Five sections of the questionnaire as following: Students' attitudes towards Palestinian resistance literature in general; Attitudes towards Palestinian resistance poetry; Attitudes towards Palestinian resistance prose (short stories, novels and plays); Attitudes towards an educational environment rich of Palestinian resistance literature; Attitudes towards the role of Palestinian literature in resistance.

\section{Validity and reliability of study tools}

After constructing the questionnaire on students' attitudes and knowledge of Palestinian resistance literature, its initial draft was presented to a panel of experienced and qualified experts in the field of education to verify its validity. Each expert was asked to present his view about each item in the questionnaire in terms of clarity. After collecting and analyzing data, the questionnaire was amended in accordance with the views of experts.

\section{Statistical treatment}

We used descriptive and analytical statistical methods. The descriptive methods are characterized in mathematical averages, standard deviations, and percentages. The analytical methods are characterized in t-test and one-way ANOVA.

\section{Results}

The following key has been used to judge the paragraphs of the questionnaires: An average of less than 2.33 indicates a low score; an average of 2.33 - 3.67, indicates a moderate score; an average of more than 3.67 indicates a high score.

Question 1: What are the attitudes of students in Jerusalem towards the Palestinian Resistance Literature (revolutionary)? To answer this question, the averages and standard deviations of the level of the students' attitudes in Jerusalem towards the PRL(revolutionary), in all fields of the study and the total

\section{3}


score, were calculated as follows: Sorting of the areas of the study using the total score for each field:

\section{Insert Table 1 about here}

The data presented in Table (1) show that the level of the students' attitudes in Jerusalem towards the PRL was high in all areas of the study and in the total score; the arithmetic average of the total score is (3.95), the average of the attitudes towards the role of PRL is (4.09), the average of the attitudes towards the Palestinian resistance prose "story, novel, and drama" is (3.96), the average of the students' attitudes towards the PRL in general is (3.92), the average of the attitudes towards the Palestinian resistance poetry is(3.91), and those towards an educational environment that is rich in PRL is (3.84).

Averages and standard deviations for students' attitudes in Jerusalem towards the PRL are calculated and sorted by averages and areas of the study, as shown in tables (2), (3), (4), (5), and (6).

1- With respect to the students' attitudes towards the PRL in general, averages of the attitudes are shown in Table (2):

Insert Table 2 about here

Table (2) shows that the arithmetic mean of the total score the area was (3.92) with a standard deviation of (0.58), where the item PRL gives meaning to life" comes first (4.26) with a standard deviation of (0.81) followed by PRL represents our actual life" (4.19) with a standard deviation of (0.88), followed

\section{4}


by "PRL reinforces my self-confidence" (4.02) with a standard deviation of (0.94). The attitudes with the lowest scores were "PRL is useless at the present time" (3.43) with a standard deviation of (1.33), followed by "PRL is mere chatting and having no content" (3.75) with a standard deviation of (1.26), and also "I prefer the PRL to all types of literature" (3.82) with a standard deviation of (1.09).

2- With respect to students' attitudes towards the Palestinian resistance poetry, averages are shown in Table (3):

Insert Table 3 about here

Table (3) show that the arithmetic mean of the total score of each field is (3.91) with a standard deviation of (0.64), where the item of "The PRL signals link to land" comes first with a mean that equals (4.20) and a standard deviation of (0.92), followed by "I feel that the Palestinian Resistance poetry increases enthusiasm" (4.12) with a standard deviation of (0.99), followed by PRL is a mean to defy occupation" (4.04) with a standard deviation of (1.96). The attitudes with the lowest scores were "PRL enhances tension among people" (3.70) with a standard deviation of (1.11), followed by "I have a desire to attend the symposiums related to PRL and poetry" (3.64) with a standard deviation of (1.17), and also "I am interested in analyzing poems and Palestinian Resistance Literature" (3.60) with a standard deviation of (1.26).

3- With respect to students' attitudes towards the Palestinian resistance prose "story, novel and drama". Table (4) illustrates this:

\section{5}


Insert Table 4 about here

Table (4) shows that the arithmetic mean of the total score of the meant field is (3.96) and a standard deviation of (0.63), where the item of "I feel that the Palestinian novel emphasizes affiliation to the Palestinian land" (4.25) with a standard deviation of (0.91), followed by "I have a desire to read the Palestinian Resistance Literature" (4.16) with a standard deviation of (0.92), followed by "I feel that the Palestinian novel emphasizes affiliation to the Palestinian Identity" (4.10) with a standard deviation of (0.97).

The attitudes with the lowest scores were "I see that the exerted theatrical efforts related to Palestinian resisting play are insufficient" (3.59) with a standard deviation of (1.17), followed by "I am interested analyzing and studying the Palestinian Resistance Story" (3.79) with a standard deviation of (0.99), and also "I enjoy attending the prose plays of resistance" (3.84) and a standard deviation of (1.08).

4- With respect to students' attitudes towards an educational environment that is rich in the Palestinian resistance literature. Table (5) shows this:

Insert Table 5 about here

Table (5) shows the paragraphs related to students' attitudes towards an educational environment that is rich in the PRL sorted by averages, as the arithmetic average of the total score is (3.84) and a standard deviation of (0.76), where the item "I feel that the classroom highlights the importance of the Palestinian Resistance Literature" (3.96) with a standard

\section{6}


deviation of (1.11), followed by "I like to highlight sayings and proverbs drawn from Palestinian Resistance Literature" (3.91) with a standard deviation of (1.02), followed by "I like to see photographs of writers of resistance literature at school" (3.89), with a standard deviation of (0.99).

The attitudes with the lowest scores were "I tend to participate in competitions related to the Palestinian Resistance Literature" (3.70) with a standard deviation of (1.21), followed by "I support classroom posters derived from the Palestinian Resistance Literature" (3.77) with a standard deviation of (1.01), and also "I support nominating school facilities in the names of resistance poets"(3.79) with a standard deviation of (1.11).

5- With respect to students attitudes towards the role of literature in the Palestinian resistance. Table (6) shows this:

Insert Table 6 about here

Table (6) shows the paragraphs related to students' attitudes towards the role of literature in the Palestinian resistance sorted by averages, as the arithmetic average of the total score of the scale is (4.09) and the standard deviation is (0.70), where the item "The PRL makes a refugee feels nostalgic to homeland" (4.28) with a standard deviation of (0.89), followed by "The PRL calls for resistance" (4.26) with a standard deviation of (0.85), and followed by "The PRL calls for affiliation to the Palestinian land" (4.26) with a standard deviation of (0.84).

The attitudes with the lowest scores were "The PRL calls for resentment of treason" (3.83) with a standard deviation of

\section{7}


(1.26), followed by "The PRL calls for maintaining the traditions of resisting occupation" (3.97) with a standard deviation of (1.07) and also "The PRL reinforces the culture of refusing the current situation (status Coe)" (3.98) with a standard deviation of (1.01).

Question 2: What is the impact of some variables (sex, stage, and residence) on attitudes towards Palestinian literature among students in Jerusalem?

To answer this question, three null hypotheses have resulted and were examined as follows:

Hypothesis 1: There is no statistical significance at the level $(\alpha \geq 0.05)$ for the averages of the attitudes towards the Palestinian literature among students in Jerusalem that can be attributed to the gender variable.

To test this null hypothesis, "T" test was used for independent samples (t-test) and the averages of the response of the study sample to the paragraphs of the attitudes towards the Palestinian literature among students in Jerusalem, according to the gender variable. Table (7) illustrates this.

\section{Insert Table 7 about here}

Table (7) shows that the significance level equals 0.51 , which is bigger than the statistical level of significance $(\alpha \geq 0.05)$; i.e. there is no differences of statistical significance in the attitudes towards the Palestinian literature among students in Jerusalem that can be attributed to the gender variable. Thus, the null hypothesis 1 was accepted.

Hypothesis 2: there is no statistical significance at the level ( $\alpha$ $\geq 0.05)$ for the averages of the attitudes towards the

\section{8}


Palestinian literature among students in Jerusalem that can be attributed to the stage variable.

To test this null hypothesis, "T" test was used for independent samples (t-test) and the averages of the response of the study sample to the paragraphs of the attitudes towards the Palestinian literature among students in Jerusalem, according to the stage variable. Table (8) illustrates this.

Insert Table 8 about here

Table (8) shows that the calculated significance level equals 0.01 , which is less than the statistical level of significance $(\alpha \geq$ $0.05)$; i.e. there are differences of statistical significance in the attitudes towards the Palestinian literature among students in Jerusalem that can be attributed to the stage variable. Thus, the null hypothesis 2 not accepted

Hypothesis 3: there is no statistical significance at the level ( $\alpha$ $\geq 0.05)$ for the averages of the attitudes towards the Palestinian literature among students in Jerusalem that can be attributed to the place of residence.

To test this null hypothesis, One Way Anova Test was used for the response of the study sample to the paragraphs of the attitudes towards the Palestinian literature among students in Jerusalem, that can be attributed to the place of residence variable. Table (9) and table (10) illustrate this.

Insert Table 9 about here

Insert Table 10 about here

\section{9}

Journal of Arabic Studies in Education \& Psychology(ASEP) 
The results presented in Table (10) indicate that there are statistically significant differences at $(\alpha=0.05)$ in the averages of attitudes towards the Palestinian literature among students in Jerusalem that can be attributed to the place of residence variable, where the statistical significance was $(0.01)$ which is statistically significant in the total score. We have conducted (LSD) test for dimensional comparisons to determine the direction of the differences according to the place of residence, as indicated in the table (11).

Insert Table 11 about here

Table (11) shows that the differences in attitudes towards the Palestinian literature among students in Jerusalem according to the place of residence were between the city and the camp in the favor of the camp, and between the village and the camp in favor of the camp, which means that the students' attitudes in camps are higher than their counterparts. Thus, the null hypothesis 3 not accepted

\section{Discussion and Recommendations}

\section{Discussion}

The results showed that the level of attitudes of Jerusalem students towards PRL was high across all domains in terms of the role of PRL in general, students' attitudes towards PRL in general, attitudes towards Palestinian resistance poetry, and attitudes towards an environment rich in Palestinian resistance literature. This shows the importance of PRL in the lives of the Palestinian people due to its major role in confronting occupation, uniting the Palestinian people and boosting their morale. It tells the story of struggling people who seek their freedom; therefore, all segments of society are interested in a

\section{0}


certain form of this literature because we believe that words can achieve what weapons cannot.

Mathematical averages and standard deviations were calculated for items related to this domain, and values were high. After reviewing the results of mathematical averages and standard deviations of the various forms of Palestinian literature, the results came as expected; students preferred literature that linked them to their reality and daily tragedy under conditions imposed upon them by the occupation in suppression, tyranny and unfair policies without exception. The rights of children are not recognized by the occupation whose policy is based on killing and destruction.

There are no statistically significant differences between average attitudes towards Palestinian literature among students in Jerusalem that are attributed to the sex variable, hence all segments of society favor the literature that represents their cause, highlights their crises and suffering and revives hope of salvation from tyranny and occupation. Many poets have written about the atrocities committed by the occupation forces in order to boost the spirit of resistance and shape the personalities of Palestinian people. Female poets also wrote about the bleeding wound in the Palestinian body, and told stories from their daily lives about reality on the ground.

There are statistically significant differences in attitudes towards Palestinian literature among students in Jerusalem that are attributed to the stage variable in favor of the elementary stage. Palestinian curricula have featured resistance literature in an ascending manner from elementary to secondary stages, so the curricula taught to elementary students include notable works by prominent Palestinian resistance writers such as Ibrahim Toqan and Mahmoud Darwish. The secondary stage curricula, however, features a wide array of PRL works

\section{1}


discussed in detail. High school students enjoy greater capability to comprehend the lives of writers and their struggle against occupation; they are able to analyze novels and understand the relations between characters through place and time. For this reason, this entire generation of Palestinian is raised on a passion for resistance even by words. This literature is not a new chapter in the life of Palestinian people; it is rather a long-established element of their struggle against the occupation, as witnessed by the whole world.

On the other hand, elementary students are basically children who are influenced by stories told to them in resistance poetry, and they respond and react to such works faster than others and embrace them in their imagination. For this reason, teaching PRL to elementary students must be carefully planned and conducted in order to avoid any unwanted reactions. We aim to raise an educated generation rather than manipulating our children because unlike the rest of the world, Israeli occupation authorities take children accountable for their acts even when they are under-age and throws them in prison with no mercy.

In addition, results showed that students residing in refugee camps have better attitudes towards PRL than their peers. The Zionist attempts to erase the Arab culture in Palestine did not prevent the emergence of an educated generation with full awareness of the surrounding and eminent danger of Zionism. The more awareness the individual develops, the more ability he/she obtains to confront dangers. Although refugee camp children are the most underprivileged of all, they have clanged to the teeth to their right for education in spite of the very difficult conditions and the poor education environment provided to them. The Palestinian cause will never fall into oblivion with time, it will rather gain more heat and there will

\section{2}


come a day when rocks will scream and birds will sing that this is the Arab land of Palestine.

\section{Recommendations}

In light of the results of this study, we recommend the following:

1. Embracing the PRL by embedding it in Arabic language curricula and highlighting its significance.

2. Introducing a compulsory course on PRL to the curricula of Palestinian universities.

3. Organizing seminars and lectures on PRL with students' participation.

4. Training students continuously on interacting with PRL in poetry and prose.

\section{Acknowledgements}

We wish to thank the following: the students who completed the questionnaires; their schools and their teachers who made the necessary arrangements; the Palestinian Ministry of Education.

\section{References}

- Abu Al-Shabab, W. (1977). The Image of the Palestinian in Contemporary Palestinian Short Stories: Dar Al-Taliaa. Beirut.

- Al-Hussein, Q. (1980). Death and Life in Resistance Poetry: Dar AlRa'ed Al-Arabi. Beirut

- Al-Jozi, N. (1990). A History of Palestinian Theater (1918-1948): Nicosia. Cyprus.

- Al-Kayali, A. (1973). Modern History of Palestine: $3^{\text {rd }}$ ed: Arab Institution of Studies. Beirut.

- Al-Owaisi, A. (1992). Roots of the Palestinian Cause: $2^{\text {nd }}$ ed: Dar AlHassan. Hebron.

- Davidoff, L. (1980), Introduction to Psychology: $2^{\text {nd }}$ ed: Translated by Sayed Al-Tawai et al. McGraw-Hill, Modern Egyptian Office Press.

\section{3}


- Dowidar, A. (1998). Social Psychology: Foundations and Principles: Dar Al-Maarefa. Cairo.

- Henderson, E., Berlin, A., \& Fuller, J. (2002). Attitude of medical students towards general practice and general practitioners. British Journal of General Practice, 359-363.

- Hoffmann, L., Krapp, A., Renninger, A. \& Baumert, J. (1998). Interest and learning; proceedings of the Second Conference on Interest and Gender (Kiel, Institut für die Pädagogik der Naturwissenschaften).

- Jenkins, E.W., \& Nelson, N. W. (2005). Important but not for me: students' attitudes towards secondary school science in England. Research in Science \& Technological Education, 23(1), 41-57.

- Jomaa, H. (2009). Features in Resistance Literature: Publications of the Syrian Commission for Books and Ministry of Culture. Damascus.

- Kanafani, Gh. (1970). Resistance Literature in Occupied Palestine (1948-1966): Dar Al-Aadab. Beirut.

- Kanafani, Gh. (1980). Palestinian Resistance Literature (1948-1968): Dar Al-Aadab. Beirut.

- Lehrke, M., Hoffmann, L., \& Gardner, P. L. (1985). Interests in science and technology education (Kiel, Institut für die Pädagogik der Naturwissenschaften).

- Nashwani, A. (1985). Educational Psychology: $2^{\text {nd }}$ ed: Dar Al-Forqan. Beirut.

- Rashid, F. (2004). Resistance Culture: Dar Al-Faris. Jordan.

- Sadouq, R. (2000). Poets of Palestine in the $20^{\text {th }}$ Century: Arab Institution of Research and Publishing. Beirut.

- Schmidt, S.D., Inbar, O., \& Shohamy, E. (2004). The Effects of Teaching Spoken Arabic on Students' Attitudes andMotivation in Israel.The Modern Language Journal, 88, ii.

- Shukri, Gh. (1979). Resistance Literature: $2^{\text {nd }}$ ed: Dar Al-Afaq AlJadida. Beirut.

- Simpson, R. D., Koballa, T. R., Oliver, J. S., \& Crawley, F. E. (1994). Research in the affective dimension of science learning, in: D. Gabel (Ed.) Handbook of research on science teaching and learning (New York, Macmillan). 
- Tamir, P., \& Gardner, P. L. (1989). The structure of interest in high school biology. Research in Science \& Technological Education, 9(2), 113-140.

Table 1 . The arithmetic averages, the standard deviations, the score and the rank of each field of the study according to the study sample responses.

\begin{tabular}{|llccc|}
\hline No & \multicolumn{1}{c}{ Field } & $\begin{array}{c}\text { Averag } \\
\text { e }\end{array}$ & S.D & Score \\
\hline $\mathbf{r}$ & Attitudes towards the role of Palestinian literature in resistance & 4.09 & 0.70 & high \\
\hline $\mathbf{r}$ & $\begin{array}{l}\text { Attitudes toward the Palestinian Resistance Prose "story, Novell and } \\
\text { drama }\end{array}$ & 3.96 & 0.63 & high \\
\hline $\mathbf{r}$ & $\begin{array}{l}\text { Attitudes of students towards the Palestinian Resistance Literature in } \\
\text { general. }\end{array}$ & 3.92 & 0.58 & high \\
\hline & $\begin{array}{l}\text { Attitudes toward the Palestinian Resistance Poetry } \\
\text { Attitudes toward an educational environment that is rich in the } \\
\text { Palestinian Resistance Literature }\end{array}$ & 3.91 & 0.64 & high \\
\hline \hline The total score of this field & $\mathbf{3 . 9 5}$ & $\mathbf{0 . 2 9}$ & high \\
\hline
\end{tabular}

Table 2. The averages and standard deviations for the students' attitudes towards the PRL in general sorted by averages.

\begin{tabular}{|c|c|c|c|c|}
\hline $\begin{array}{l}\mathbf{N} \\
\mathbf{0}\end{array}$ & Paragraph & $\begin{array}{c}\text { avera } \\
\text { ge }\end{array}$ & S.D & Score \\
\hline 1 & Palestinian Resistance Literature gives meaning to life & 4.26 & 0,81 & high \\
\hline 2 & The Palestinian Resistance Literature represents our actual life. & 4.19 & 0.88 & high \\
\hline 3 & Palestinian Resistance Literature reinforces my self-confidence & 4.02 & 0.94 & high \\
\hline 4 & $\begin{array}{l}\text { I feel the originality of Arabic through the Palestinian Resistance } \\
\text { Literature }\end{array}$ & 4.00 & 0.98 & high \\
\hline 5 & $\begin{array}{l}\text { I see that the Palestinian Resistance Literature connects between the } \\
\text { political, economic and social issues. }\end{array}$ & 3.98 & 0.96 & high \\
\hline 6 & $\begin{array}{l}\text { There must be a special curriculum focusing the Palestinian Resistance } \\
\text { Literature }\end{array}$ & 3.92 & 1.15 & high \\
\hline 7 & $\begin{array}{l}\text { I am interested in keeping books related to Palestinian Resistance } \\
\text { Literature }\end{array}$ & 3.84 & 0.90 & high \\
\hline 8 & I prefer the Palestinian Resistance Literature to all types of literature & 3.82 & 1.09 & high \\
\hline 9 & $\begin{array}{l}\text { Palestinian Resistance Literature is mere chatting and having no } \\
\text { content }\end{array}$ & 3.75 & 1.26 & high \\
\hline 10 & Palestinian Resistance Literature is useless at the present time & 3.43 & 1.33 & $\begin{array}{l}\text { moder } \\
\text { ate }\end{array}$ \\
\hline & The total score of this field & 3.92 & 0.58 & high \\
\hline
\end{tabular}

Table 3. The averages and standard deviations for the students' attitudes towards the Palestinian resistance poetry sorted by averages.

\begin{tabular}{|clccc|}
\hline No & \multicolumn{1}{c}{ Paragraph } & average & S.D & Score \\
\hline $\mathbf{1 1}$ & The Palestinian Resistance Literature signals link to land & 4.20 & 0.92 & high \\
\hline $\mathbf{1 2}$ & $\begin{array}{l}\text { I feel that poets of the Palestinian Resistance Literature are a } \\
\text { permanent symbol of life and affiliation to land. }\end{array}$ & 4.20 & 0.96 & high \\
\hline $\mathbf{1 3}$ & I feel that the Palestinian Resistance poetry increases enthusiasm & 4.12 & 0.99 & high \\
\hline $\mathbf{1 4}$ & Palestinian Resistance Literature is a mean to defy occupation. & 4.04 & 1.06 & high \\
\hline $\mathbf{1 5}$ & I feel relaxed when I hear the Palestinian Resistance Literature & 3.97 & 1.01 & high \\
\hline $\mathbf{1 6}$ & $\begin{array}{l}\text { Poetry and poems of Palestinian Resistance Literature cause } \\
\text { frustration. }\end{array}$ & 3.88 & 1.29 & high \\
\hline $\mathbf{1 7}$ & I tend to recite the Palestinian Resistance poems and poetry. & 3.78 & 1.01 & high \\
\hline $\mathbf{1 8}$ & $\begin{array}{l}\text { I am interested in analyzing poems and Palestinian Resistance } \\
\text { Literature }\end{array}$ & 3.70 & 1.11 & high \\
\hline $\mathbf{1 9}$ & $\begin{array}{l}\text { I have a desire to attend the symposiums related to Palestinian } \\
\text { Resistance Literature and poetry }\end{array}$ & 3.64 & 1.17 & moderate \\
\hline $\mathbf{2 0}$ & Palestinian resistance literature enhances tention among people & 3.60 & 1.26 & moderate \\
\hline \hline The total score of this field & $\mathbf{3 . 9 1}$ & $\mathbf{0 . 6 4}$ & high \\
\hline
\end{tabular}


Table 4. The averages and standard deviations of the attitudes towards the Palestinian resistance prose "story, novel and drama" sorted by averages.

\begin{tabular}{|c|c|c|c|c|}
\hline No & Paragraph & average & S.D & Score \\
\hline 21 & $\begin{array}{l}\text { I feel that the Palestinian novel emphasizes affiliation to the } \\
\text { Palestinian land }\end{array}$ & $4.25^{\circ}$ & 0.91 & high \\
\hline 22 & I have a desire to read the Palestinian Resistance Literature & 4.16 & 0.92 & high \\
\hline 23 & $\begin{array}{l}\text { I feel that the Palestinian novel emphasizes affiliation to the } \\
\text { Palestinian Identity. }\end{array}$ & 4.10 & 0.97 & high \\
\hline 24 & $\begin{array}{l}\text { I feel that the Palestinian resistance novel gives a feeling of victory } \\
\text { atmosphere }\end{array}$ & 4.06 & 1.00 & high \\
\hline 25 & $\begin{array}{l}\text { I connect the Palestinian Resistance stories to incidents in our daily } \\
\text { life. }\end{array}$ & 4.05 & 0.89 & high \\
\hline 26 & $\begin{array}{l}\text { I prefer the Palestinian novel that represents the character of a } \\
\text { resisting man }\end{array}$ & 4.02 & 0.97 & high \\
\hline 27 & $\begin{array}{l}\text { I feel that the Palestinian Resistance Theater expresses the concerns } \\
\text { and issues of Palestinians. }\end{array}$ & 4.01 & 0.95 & high \\
\hline 28 & $\begin{array}{l}\text { I am interested in Palestinian resisting novel as it includes } \\
\text { revolutionary ethics }\end{array}$ & 3.95 & 0.98 & high \\
\hline 29 & $\begin{array}{l}\text { I am interested in the Palestinian stories that highlight the } \\
\text { Revolutionary Palestinian event. }\end{array}$ & 3.95 & 1.01 & high \\
\hline 30 & I like the Palestinian stories that glorify the resisting person. & 3.89 & 0.97 & high \\
\hline$r_{1}$ & $\begin{array}{l}\text { I am interested in Palestinian plays related to the Palestinian } \\
\text { revolutionary movements }\end{array}$ & 3.86 & 1.05 & high \\
\hline 32 & $\begin{array}{l}\text { I prefer the Resistance Palestinian plays that represent a revolution } \\
\text { against the current depressing political circumstances. }\end{array}$ & 3.85 & 1.08 & high \\
\hline 33 & I enjoy attending the prose plays of resistance & 3.84 & 1.08 & high \\
\hline 34 & $\begin{array}{l}\text { I am interested analyzing and studying the Palestinian Resistance } \\
\text { Story }\end{array}$ & 3.79 & 0.99 & high \\
\hline 35 & $\begin{array}{l}\text { I see that the exerted theatrical efforts related to Palestinian resisting } \\
\text { play are insufficient. }\end{array}$ & 3.59 & 1.17 & $\begin{array}{c}\text { moder } \\
\text { ate }\end{array}$ \\
\hline \multicolumn{2}{|c|}{ The total score of this field } & 3.96 & 0.63 & high \\
\hline
\end{tabular}

Table 5. The averages and standard deviations of the attitudes towards an educational environment that is rich in the PRL sorted by averages.

\begin{tabular}{|c|c|c|c|c|}
\hline No & Paragraph & average & S.D & Score \\
\hline 4 & $\begin{array}{l}\text { I feel that the classroom highlights the importance of the Palestinian } \\
\text { Resistance Literature }\end{array}$ & 3.96 & 1.11 & high \\
\hline 37 & $\begin{array}{l}\text { I like to highlight sayings and proverbs drawn from Palestinian } \\
\text { Resistance Literature }\end{array}$ & 3.91 & 1.02 & high \\
\hline 38 & I like to see photographs of writers of resistance literature at school & 3.89 & 0.99 & high \\
\hline 39 & $\begin{array}{l}\text { I tend that morning speeches that includes a Resisting Palestinian } \\
\text { Literature }\end{array}$ & 3.89 & 1.09 & high \\
\hline 40 & $\begin{array}{l}\text { I prefer to form a cultural school committee that highlights Palestinian } \\
\text { Resistance Literature }\end{array}$ & 3.88 & 1.02 & high \\
\hline ؛ & $\begin{array}{l}\text { I Favor the integration of Palestinian literature resistor in school } \\
\text { activities }\end{array}$ & 3.87 & 1.06 & high \\
\hline 42 & $\begin{array}{l}\text { I prefer to highlight the curricular activities related to Resisting } \\
\text { Palestinian Literature. }\end{array}$ & 3.83 & 1.07 & high \\
\hline$\{3$ & I support nominating school facilities in the names of resistance poets & 3.79 & 1.11 & high \\
\hline 44 & I support classroom posters derived from the PRL & 3.77 & 1.01 & high \\
\hline$\leqslant 0$ & $\begin{array}{l}\text { I tend to participate in competitions related to the Palestinian } \\
\text { Resistance Literature }\end{array}$ & 3.70 & 1.21 & high \\
\hline \multicolumn{2}{|c|}{ The total score of this field } & 3.84 & 0.76 & high \\
\hline
\end{tabular}


Table 6 . The averages and standard deviations for students' attitudes towards the role of literature in the Palestinian resistance sorted by averages

\begin{tabular}{|c|c|c|c|c|}
\hline No & Paragraph & average & S.D & $\begin{array}{c}\text { Sco } \\
\text { re }\end{array}$ \\
\hline \&6 & $\begin{array}{l}\text { The Palestinian resistance Literature makes a refugee feels } \\
\text { Nostalgia to homeland }\end{array}$ & 4.28 & 0.89 & high \\
\hline ? 7 & The Palestinian Resistance Literature calls for resistance & 4.26 & 0.85 & high \\
\hline$\leq 8$ & $\begin{array}{l}\text { The Palestinian resistance Literature calls for affiliation to the } \\
\text { Palestinian land }\end{array}$ & 4.26 & 0.84 & high \\
\hline 49 & $\begin{array}{l}\text { The Palestinian resistance Literature calls for faithfulness to } \\
\text { martyrs. }\end{array}$ & 4.17 & 1.00 & high \\
\hline 50 & The Palestinian resistance Literature urges prisoners for patience & 4.13 & 0.99 & high \\
\hline$\cdot 01$ & The Palestinian resistance Literature supports the martyr's mother & 4.12 & 0.94 & high \\
\hline 02 & $\begin{array}{l}\text { The Palestinian resistance Literature calls for refusing injustices } \\
\text { and cruelty }\end{array}$ & 4.11 & 0.99 & high \\
\hline -33 & The Palestinian resistance Literature supports prisoners' mothers & 4.07 & 1.02 & high \\
\hline 54 & $\begin{array}{l}\text { The Palestinian resistance Literature urges people to cooperation } \\
\text { and solidarity }\end{array}$ & 4.05 & 0.99 & high \\
\hline 55 & $\begin{array}{l}\text { The Palestinian resistance Literature calls for boycotting } \\
\text { naturalization with occupation }\end{array}$ & 3.99 & 1.12 & high \\
\hline 04 & $\begin{array}{l}\text { The Palestinian resistance Literature reinforces the culture of } \\
\text { refusing the current situation(status Coe) }\end{array}$ & 3.98 & 1.01 & high \\
\hline 07 & $\begin{array}{l}\text { The Palestinian resistance Literature calls for maintaining the } \\
\text { traditions of resisting occupation }\end{array}$ & 3.97 & 1.07 & high \\
\hline$\bullet 8$ & The Palestinian resistance Literature calls for resentment of treason & 3.83 & 1.26 & high \\
\hline \multicolumn{2}{|c|}{ The total score of this field } & 4.09 & 0.70 & high \\
\hline
\end{tabular}

Table 7. t-test results for independent samples in attitudes towards the Palestinian literature among students in Jerusalem, according to the gender variable

\begin{tabular}{|lccccc|}
\hline Gender & Number & Average & $\begin{array}{l}\text { Standard } \\
\text { deviation }\end{array}$ & "t" value & $\begin{array}{l}\text { Significance } \\
\text { level }\end{array}$ \\
\hline Male & 700 & 3.96 & 0.58 & 0.66 & $\mathbf{0 . 5 1}$ \\
\hline \hline Female & $\mathbf{6 0 2}$ & $\mathbf{3 . 9 4}$ & $\mathbf{0 . 5 5}$ & & \\
\hline
\end{tabular}

Table 8. t-test results for independent samples in attitudes towards the Palestinian literature among students in Jerusalem, according to the stage variable

\begin{tabular}{|llllll|}
\hline Stage & Number & Average & $\begin{array}{l}\text { Standard } \\
\text { deviation }\end{array}$ & $\begin{array}{l}\text { "t" } \\
\text { value }\end{array}$ & $\begin{array}{l}\text { significance } \\
\text { level }\end{array}$ \\
\hline Basic & 290 & 4.11 & 0.53 & 5.92 & $\mathbf{0 . 0 1}^{*}$ \\
\hline \hline Secondary & $\mathbf{1 0 1 2}$ & $\mathbf{3 . 8 9}$ & $\mathbf{0 . 5 6}$ & & \\
\hline
\end{tabular}

Statistically significant at the level $(\alpha \geq 0.05)$

Table 9. Averages and standard deviations of the attitudes towards the Palestinian literature among students in Jerusalem that can be attributed to the place of residence variable

\begin{tabular}{|llll|}
\hline Place of residence & Number & Average & $\begin{array}{l}\text { Standard } \\
\text { deviation }\end{array}$ \\
\hline City & NIr & 3.94 & 0.56 \\
\hline Village & rYr & 3.90 & 0.54 \\
\hline Camp & Irr & 4.07 & 0.62 \\
\hline
\end{tabular}

Table 10. Results of the analysis of variance (ANOVA) test for the differences in the averages of the attitudes towards the Palestinian literature among students in Jerusalem attributed to the place of residence variable

\begin{tabular}{|l|l|l|l|l|l|}
\hline Variance source & $\begin{array}{l}\text { The total of } \\
\text { squares }\end{array}$ & $\begin{array}{l}\text { Degrees of } \\
\text { freedom }\end{array}$ & $\begin{array}{l}\text { Squares } \\
\text { average }\end{array}$ & $\begin{array}{l}\text { Calculated } \\
\text { "F" value }\end{array}$ & $\begin{array}{l}\text { Statistical } \\
\text { significance }\end{array}$ \\
\hline Between groups & 2.86 & 2 & 1.43 & 4.52 & $0.01 *$ \\
\cline { 1 - 2 } Inside groups & 4.12 .17 & 1299 & 0.317 & & \\
\hline Total & & 1301 & & & \\
\hline
\end{tabular}

Statistically significant at the level $(\alpha \geq 0.05)$ 
Table 11. The results of (LSD) test according to the place of residence

\begin{tabular}{|c|c|c|c|c|}
\hline & I & $\mathbf{J}$ & I-J & significance \\
\hline \multirow{6}{*}{$\begin{array}{l}\text { The attitudes towards the } \\
\text { Palestinian literature among } \\
\text { students in Jerusalem according to } \\
\text { the place of residence }\end{array}$} & City & Village & 0.05 & 0.19 \\
\hline & & Camp & $0.13-$ & $0.01 *$ \\
\hline & Village & City & $0.05-$ & 0.19 \\
\hline & & Camp & $0.17-$ & $0.00 *$ \\
\hline & Camp & City & $\cdot, 1 T$ & 0.01* \\
\hline & & Village & 0.17 & $0.00 *$ \\
\hline
\end{tabular}

Statistically significant at the level $(\alpha \geq 0.05)$

اسماء الباحثين

اتجاهات طلبة مدينة القدس نحو الأدب القلسطيني المقاوم

هبه ابر اهيم علي بركاتـ كلية التربية_جامعة غرناطة. اسباتيا لإنين

hiba_barakat@windowslive.com

خوسيه لويس مارتن اورتيكا- كلية التربيةجامعة غرناطة ـ اسباتيا

ortegam@ugr.es

عفيف زيدان كلية العلوم التربوية_ جامعة القدس. فلسطين

afzeidan@edu.alquds.edu

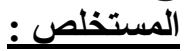

هذه الورقة تهدف الى الاطلاع على اتجاهات طلبة مدينة القدس نحو الأدب الفلسطيني المقاوم و المله

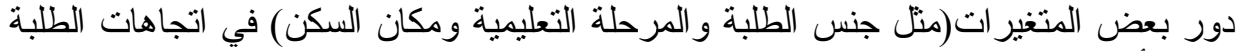

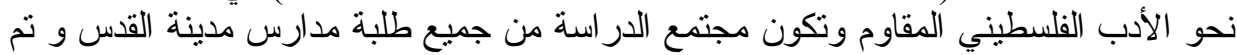

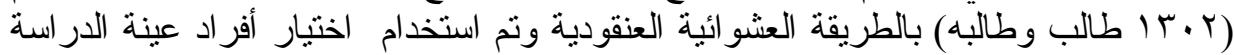

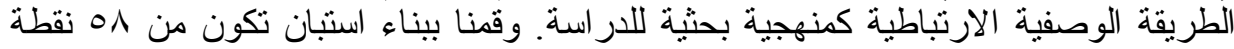

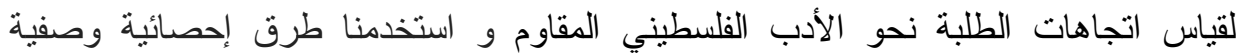

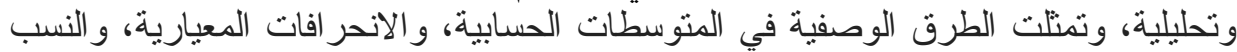
one-way

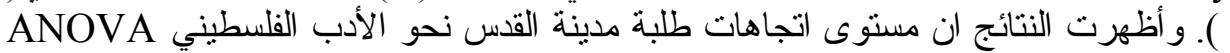

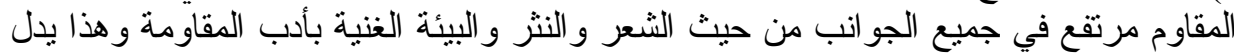

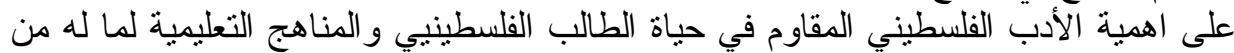

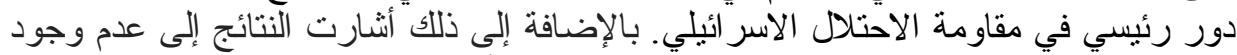

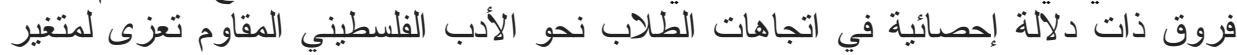
الجنس. ووجود فروق دالة الحصائيا في متغير المرحلة الدراسية ولصالح المرحلة الاساسية ومتغير مكان السكن ولصالح طلبة المخيمات.

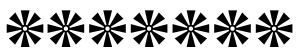

\section{8}

